Marine Fishes of New Zealand by Eric Heath and John M. Moreland. Bailey Bros and Swinfen, 26s.

This book, nicely produced in Japan, contains 23 colour plates by Eric Heath realistically depicting 100 species, perhaps one quarter of the total fish-fauna of New Zealand seas. Conveniently facing each plate are concise notes on the distribution, distinguishing characters, food, popular names and usual methods of capturing each species, by John Moreland, ichthyologist at the Dominion Museum, Wellington, who also contributes a short general introduction on the identification, coloration, distribution, major classification, forms, habits and swimming of fishes, together with a brief glossary.

The sharks and rays are treated together, but the bony fishes are grouped according to the depths of their habitats, an arrangement which produces some odd juxtapositions of unrelated species and really calls for a page of tabular classification. It is useless to complain that there are no references to further reading, for there is little or no comprehensive literature available on New Zealand fishes. Furthermore, the deposition of type-specimens (often of widelydistributed or even cosmopolitan species) in European and American museums, coupled with a shortage of literature and lack of world-wide comparative collections in their own, has led to a great deal of nomenclatorial confusion among antipodean ichthyologists.

We may hope that Messrs Heath and Moreland will persevere towards the eventual production of a much-needed comprehensive Peterson-type field guide. In the meantime the present book will give much assistance to New Zealand anglers and naturalists, while the British reader will be surprised to discover that the New Zealand marine fish-fauna presents a general aspect curiously familiar to him.

DENYS W. TUCKER

\title{
Säugetierschutz (Mammal Preservation) by Gustav Kirk. Gustav Fischer, Stuttgart, DM 9.80. \\ Demökologie: The Structure and Dynamics of Animal Popu- lations by Fritz Schwertfeger. Paul Parey, Hamburg, DM 84.
}

The greater part of Gustav Kirk's useful reference book is a survey, by orders, of the protection given to mammals throughout the world. Accuracy and detail can clearly be no better than the information available, and great effort has been made to get what there is. The bibliography has some 1500 entries, drawn from all countries and fully referenced in the text; several pages of acknowledgment show the extent of his correspondence. This is a most useful list for workers in this field.

In sketching the history of conservation he stresses its close relation to true hunting, well exemplified in his own country, Germany, where the larger mammals have long been treated with proper respect. This relation explains, to a considerable degree, the status of game in East and South Africa today, in striking contrast to other parts of that continent. The book is livened by numerous pleasant pen-and-ink drawings.

The title of Professor Schwertfeger's second of three volumes, with the general title of Animal Ecology, describes its scope. The first section deals with the structure of populations - density, distribution, age classes and sexual patterns, as well as with their relationship with their surroundings, and describes methods of collecting this information. The second section is concerned with population dynamics; variations in distribution and density are treated in detail, with special reference to the causes, and there are numerous illustrations. The author is 